Syntax Literate : Jurnal Ilmiah Indonesia p-ISSN: 2541-0849

e-ISSN : 2548-1398

Vol. 5, No. 5 Mei 2020

\title{
PENGENDALIAN KUALITAS DENGAN METODE SIX SIGMA UNTUK MENEKAN TINGKAT KERUSAKAN PRODUK
}

\author{
Lili Karmela Fitriani dan Aglin Tiara Putry \\ Universitas Kuningan (UNIKU) \\ Email: lili@uniku.ac.id dan tiaraputryaglin@gmail.com
}

\begin{abstract}
Every company must be able to compete by improving the quality of products and services provided to consumers. The study using Six Sigma method to determine quality control through several stages, namely definie, measure, analyse, improve, control. The result of the study using Six Sigma method, it can be seen that the level of sigma in 2018 by DA companies is at the level of $3.9 \sigma$ with the DPMO value at 8655,54. The defect experienced by the company of 3 main types, namely invitations that experience blurry colors, clipped writing and italics. The factors that cause defect include tools and machine, human, raw materials, and methods.
\end{abstract}

Keywords: DMAIC, Fishbone, Pareto, Quality Control, Six Sigma.

\section{Abstrak}

Setiap perusahaan harus dapat bersaing dengan meningkatkan kualitas produk dan layanan yang diberikan kepada konsumen. Penelitian ini menggunakan metode Six Sigma untuk menentukan kontrol kualitas melalui beberapa tahap, yaitu definisi, pengukuran, analisis, peningkatan, kontrol. Hasil penelitian menggunakan metode Six Sigma, dapat dilihat bahwa tingkat sigma pada tahun 2018 oleh perusahaan DA berada pada level 3,9 $\sigma$ dengan nilai DPMO pada 8655,54. Cacat yang dialami oleh perusahaan dari 3 jenis utama, yaitu undangan yang mengalami warna buram, tulisan terpotong dan miring. Faktor-faktor yang menyebabkan cacat termasuk alat dan mesin, manusia, bahan baku, dan metode.

Kata kunci: DMAIC, Tulang Ikan, Pareto, Kontrol Kualitas, Six Sigma.

\section{Pendahuluan}

Dalam memulai kegiatan usaha bukan hanya ada perencaanaan yang matang tetapi juga harus sudah disiapkan berkaitan dengan modal usaha untuk berlangsungnya kegiatan usaha yang akan dirintis ataupun kegiatan usaha yang akan dikembangkan (Hasim, 2019).

Setiap perusahaan harus mempunyai program jaminan kualitas yang efektif yaitu dengan cara selalu dilakukan pengawasan dan peningkatan terhadap kualitas produknya, Produk yang dihasilkan dalam suatu proses produksi tidak selalu menghasilkan produk yang sempurna, terkadang produk yang dihasilkan tidak sesuai dengan standar yang telah ditetapkan oleh perusahaan. Produk yang tidak sesuai dengan standar dapat dianggap sebagai produk rusak (defect) yang tidak dapat disalurkan ke pasar. Hal ini 
cukup berdampak pada keuangan perusahaan karena adanya biaya yang terbuang akibat produk cacat tersebut (Oktavianus \& Caesaron, 2017) Implementasi spesifikasi kualitas melalui berbagai sistem manajemen mutu yang berkesinambungan merupakan langkah yang baik yang harus dikerjakan oleh bagian produksi sebelum melepas produknya ke pasar (Rimantho \& Mariani, 2017).

Tabel 1

Jumlah Produksi dan Produk Cacat serta Jenis Produk Cacat Persetakan Undangan DA Tahun 2018

\begin{tabular}{lllllll}
\hline \multirow{2}{*}{ Bulan } & $\begin{array}{l}\text { Jumlah } \\
\text { Produksi } \\
\text { (buah) }\end{array}$ & $\begin{array}{l}\text { Jenis Produk Cacat } \\
\text { Miring }\end{array}$ & $\begin{array}{l}\text { Warna } \\
\text { (buah) }\end{array}$ & $\begin{array}{l}\text { Terpotong } \\
\text { (buah) }\end{array}$ & $\begin{array}{l}\text { Jumlah } \\
\text { Cacat } \\
\text { (buah) }\end{array}$ & $\begin{array}{l}\text { Presentase } \\
\text { (buah) }\end{array}$ \\
\hline Januari & 8700 & 57 & 120 & 55 & 232 & $2,67 \%$ \\
\hline Februari & 8050 & & 220 & & 220 & $2,73 \%$ \\
\hline Maret & 6500 & 55 & 178 & & 233 & $3,58 \%$ \\
\hline April & 8200 & & 155 & & 155 & $1,89 \%$ \\
\hline Mei & 6550 & & 179 & 55 & 234 & $3,57 \%$ \\
\hline Juni & 8500 & 100 & 80 & 80 & 260 & $3,06 \%$ \\
\hline Juli & 9500 & 121 & 144 & 98 & 363 & $3,82 \%$ \\
\hline Agustus & 7900 & 120 & & 77 & 197 & $2,49 \%$ \\
\hline September & 8800 & & 45 & 182 & 227 & $2,58 \%$ \\
\hline Oktober & 8200 & & 220 & & 220 & $2,68 \%$ \\
\hline November & 9500 & 150 & & & 150 & $1,58 \%$ \\
\hline Desember & 11500 & & 100 & 55 & 155 & $1,35 \%$ \\
\hline Total & $\mathbf{1 0 1 9 0 0}$ & $\mathbf{6 0 3}$ & $\mathbf{1 4 4 1}$ & $\mathbf{6 0 2}$ & $\mathbf{2 6 4 6}$ & \\
\hline Rata-rata & $\mathbf{8 4 9 2}$ & & & & $\mathbf{2 3 0}$ & $\mathbf{2 , 7 1 \%}$ \\
\hline
\end{tabular}

Sumber : PT DA, 2019

Fenomena empiris menunjukkan bahwa produksi percetakan undangan masih menghasilkan produk cacat dimana jumlah kecacatan berbeda pada setiap bulannya. Perusahaan DA menghasilkan produk undangan yaitu sebanyak 101900 buah dan memiliki total cacat 2646 buah selama 1 tahun (Januari-Desember) tahun 2018. Adapun rata-rata produksi per bulan 8492 buah dengan rata-rata produk cacat sebesar 230 buah atau sekitar $2,71 \%$ dari total produksi setiap bulan. Perusahaan DA memiliki batas toleransi yang telah ditetapkan yaitu tidak lebih dari $2 \%$ jika dilihat dari data di atas perusahaan mengalami tingkat kecacatan lebih dari $2 \%$. Sehingga hal tersebut dapat mengakibatkan kerugian terhadap perusahaan itu sendiri dikarenakan terbuangnya biaya, terkurasnya tenaga, dan penghabisan bahan baku secara percuma karena produk cacat tersebut.

Menurut penelitian (Anwar, Narto, \& Achmadi, 2017) pada produk paper packaging menyatakan bahwa dengan menggunakan metode Six Sigma maka nilai defect dapat diminimasi. (Gupta, 2013) menyimpulkan bahwa dengan menggunakan tahap DMAIC dapat mengurangi atau menghilangkan cacat pada proses produksi benang. Berbeda dengan hasil penelitian dilakukan (Sari, 2016) pada produk botol minum plastik menyatakan bahwa dengan menggunakan metode Six Sigma belum dapat 
menekan tingkat usaha (Pande, Neuman, \& Cavanagh, 2002). Metode Six Sigma dapat menekan tingkat kecacatan produk yang dihasilkan perusahaan (Pathak \& Desai, 2011) (Herdiana, 2015) kerusakan. Six Sigma dapat diterapkan di bidang usaha apa saja mulai dari perencanaan strategi sampai operasional hingga pelayanan pelanggan dan maksimalisasi motivasi atas (Manohar \& Balakrishna, 2015) (Kusumawati \& Fitriyeni, 2017), (Shofa \& Gunawan, 2017).

\section{Metode Penelitian}

Penelitian yang digunakan adalah penelitian kuantitatif dengan metode observasi yaitu pengumpulan data dengan melakukan wawancara langsung kepada pihak perusahaan dan mengamati secara langsung terhadap objek penelitian yang bersangkutan. Sampel dalam penelitian ini adalah data produksi percetakan undangan yang mengalami kecacatan pada tahun 2018 terhitung dari bulan Januari - Desember sebanyak 2646 buah undangan. Sumber data yang digunakan dalam penelitian ini adalah data sekunder yang merupakan data yang diperoleh dari sumber yang sudah ada. Data diolah dengan menggunakan metode Six Sigma dan dengan tahap Define $\rightarrow$ Measure $\rightarrow$ Analyze $\rightarrow$ Improve $\rightarrow$ Control (DMAIC) untuk mendapatkan fakta mengenai pengendalian kualitas produk di perusahaan DA.

\section{Hasil dan Pembahasan}

\section{Define (Indentifikasi Permasalahan)}

Perusahaan memiliki batas toleransi yang telah ditetapkan yaitu tidak lebih dari $2 \%$, jika dilihat dari data di atas perusahaan mengalami tingkat kecacatan lebih dari $2 \%$. Perusahaan DA memiliki total cacat sekitar 2646 buah selama 12 bulan (Januari-Desember) tahun 2018. Adanya masalah yang terjadi di perusahaan DA maka tujuan dari penerapan metode Six Sigma dengan tahap DMAIC yaitu untuk menekan tingkat kecacatan percetakan undangan di perusahaan DA.

2. Measure (Perhitungan) Tahap selanjutnya yaitu perhitungan nilai DPMO

$$
\begin{aligned}
& \mathrm{DPMO}=\frac{\text { Jumlah cacat }}{\text { Sample yang diterima } x C T Q} X 1.000 .000 \\
& \mathrm{DPMO}=\frac{2646}{101900 \times 3} \times 1.000 .000=8655,54
\end{aligned}
$$

Nilai DPMO pada percetakan undangan pada tahun 2018 adalah 8655,54 perjuta produksi dengan tingkat sigma secara keseluruhan sebesar $3,9 \sigma$, dengan demikian tingkat sigma yang dicapai oleh perusahaan tersebut sudah terbilang cukup bagus untuk ukuran industri kecil menengah karena pada tingkat 3,9б.

3. Membuat Peta Kendali (Control Chart)

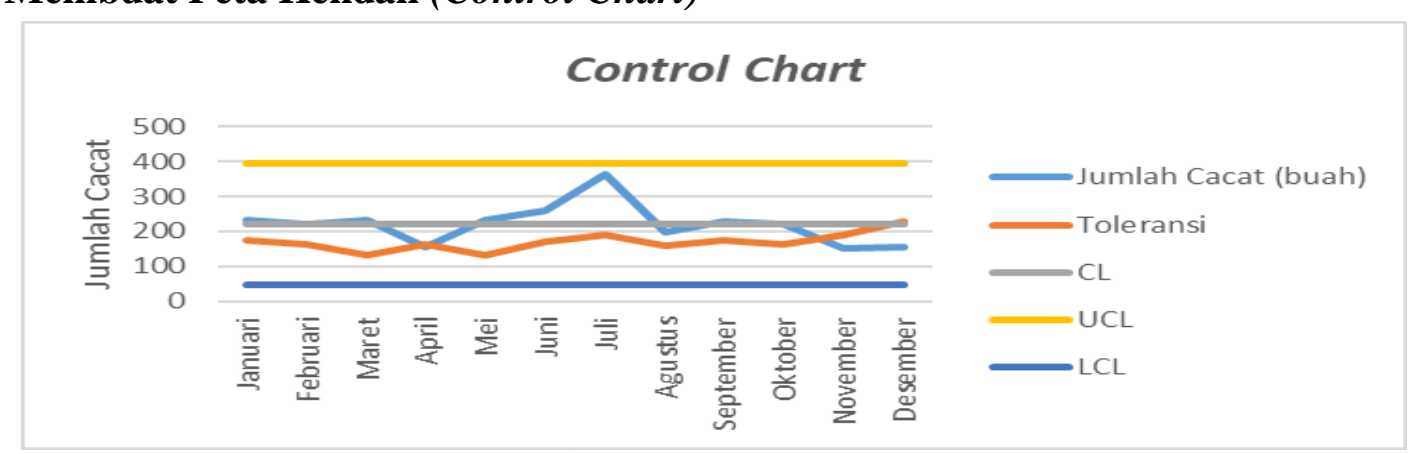

Gambar 2 Pareto Chart Jenis Kecacatan Undangan 
Hasil memperoleh nilai tengah (mean) sebesar 220,50 standar deviation 57,59 Upper Control Limit (UCL) sebesar 393,27 dan Lower Control Limit (LCL) sebesar 47,73.

\section{Analyse (Identifikasi Sumber Kecacatan)}

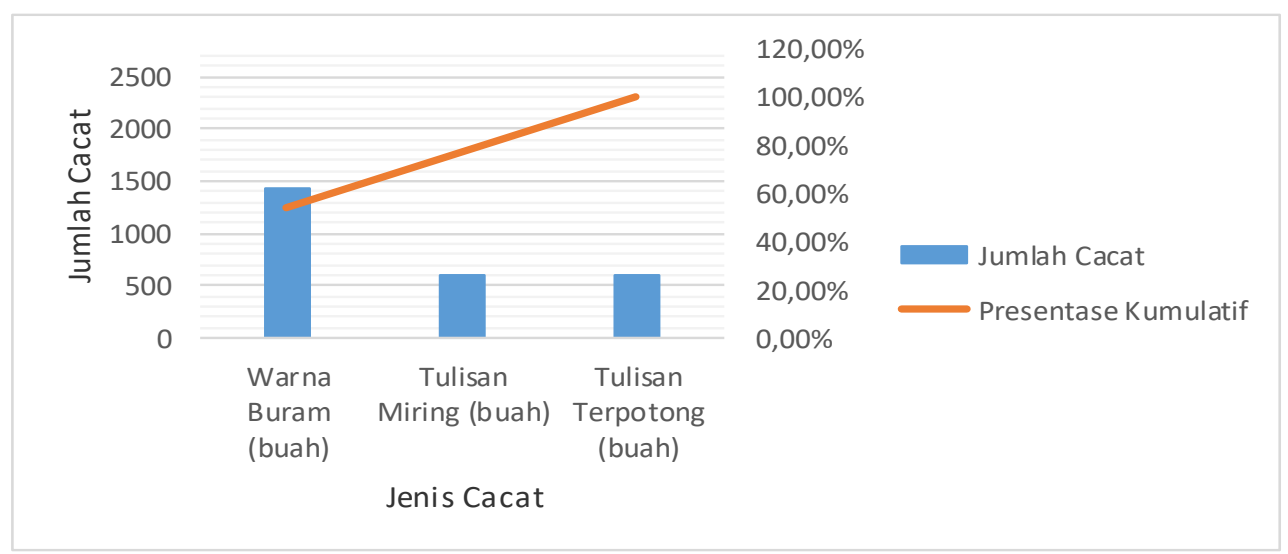

Sumber: Data yang telah diolah (2019)

\section{Gambar 3 Pareto Chart}

Hasil yang didapat dari pareto chart diatas, maka akan diterapkan alat analisis untuk mengetahui faktor-faktor penyebab kecacatan dengan menggunakan fishbone diagram atau diagram tulang ikan (sebab-akibat).

\section{Analisis Fishbone}

Beberapa faktor yang menjadi penyebab kerusakan pada produk undangan, antara lain sebagai berikut berdasarkan analisis fishbone.

a. Alat dan Mesin

Alat dan mesin merupakan faktor utama yang berpengaruh pada proses produksi. Apabila ada kerusakan dan kurangnya perawatan pada alat dan mesin, maka dapat menghambat proses produksi dan proses produksi tidak dapat berjalan sebagaimana mestinya. Begitu pula tenaga listrik yang panas dan tidak stabil bahkan sikring putus juga berakibat pada proses produksi, yaitu berpengaruh pada hasil cetakan seperti cetakan tidak rata, kertas menggulung dan kecepatan mesin berkurang sehingga proses produksi menjadi lama.

b. Manusia

Ketelitian dan kehati-hatian sangat diperlukan dalam proses produksi. Kecerobohan dan tidak bertanggung jawab dalam bekerja dapat mengakibatkan kurangnya ketelitian karyawan dalam melakukan tugasnya, karena dalam melakukan sesuatu harus teliti dan berhati-hati agar terhindar dari masalah yang dapat merugikan bagi diri sendiri maupun perusahaan seperti kegagalan dalam proses produksi. Kelelahan dapat mengakibatkan kesalahan dalam pembuatan design seperti typo atau penempatan posisi yang tidak sesuai, kurangnya konsentrasi ini dapat menyebabkan karyawan dalam melakukan pekerjaan tidak maksimal.

c. Bahan Baku

Bahan baku yang disimpan kurang baik menyebabkan menurunnya kualitas bahan baku seperti tumpukan kertas yang langsung disimpan di lantai 
tanpa alas serta penyimpanan tinta di tempat terbuka menyebabkan tinta mengering dan tinta yang mengering dapat menyebabkan tersumbatnya aliran tinta pada mesin, serta penyimpanan kertas yang tidak rata sering mengakibatkan terjadi tulisan terpotong.

d. Metode

Pada saat proses produksi berlangsung pengawasan pada box tinta masih kurang sehingga menyebabkan hasil dari percetakan undangan mengalami keburaman pada hasil cetakan, hal ini disebabkan karena mixing tinta yang tidak merata. Pengawasan pada roll mesin dan kertas yang tidak optimal juga mengakibatkan jalan kertas tidak sejajar sehingga banyak cetakan yang mengalami tulisan yang miring, serta proses pemotongan kertas yang tidak akurat juga menyebabkan tulisan terpotong.

\section{Improve (Usulan Perbaikan)}

Beberapa faktor yang menjadi penyebab kecacatan produk undangan, maka tahap selanjutnya yaitu melakukan tahap usulan perbaikan kepada perusahaan untuk mengetahui sebab dan akibat apa yang terjadi pada perusahaan percetakan DA, berikut adalah beberapa usulan perbaikan guna mengatasi dari beberapa faktor penyebab kecacatan tersebut.

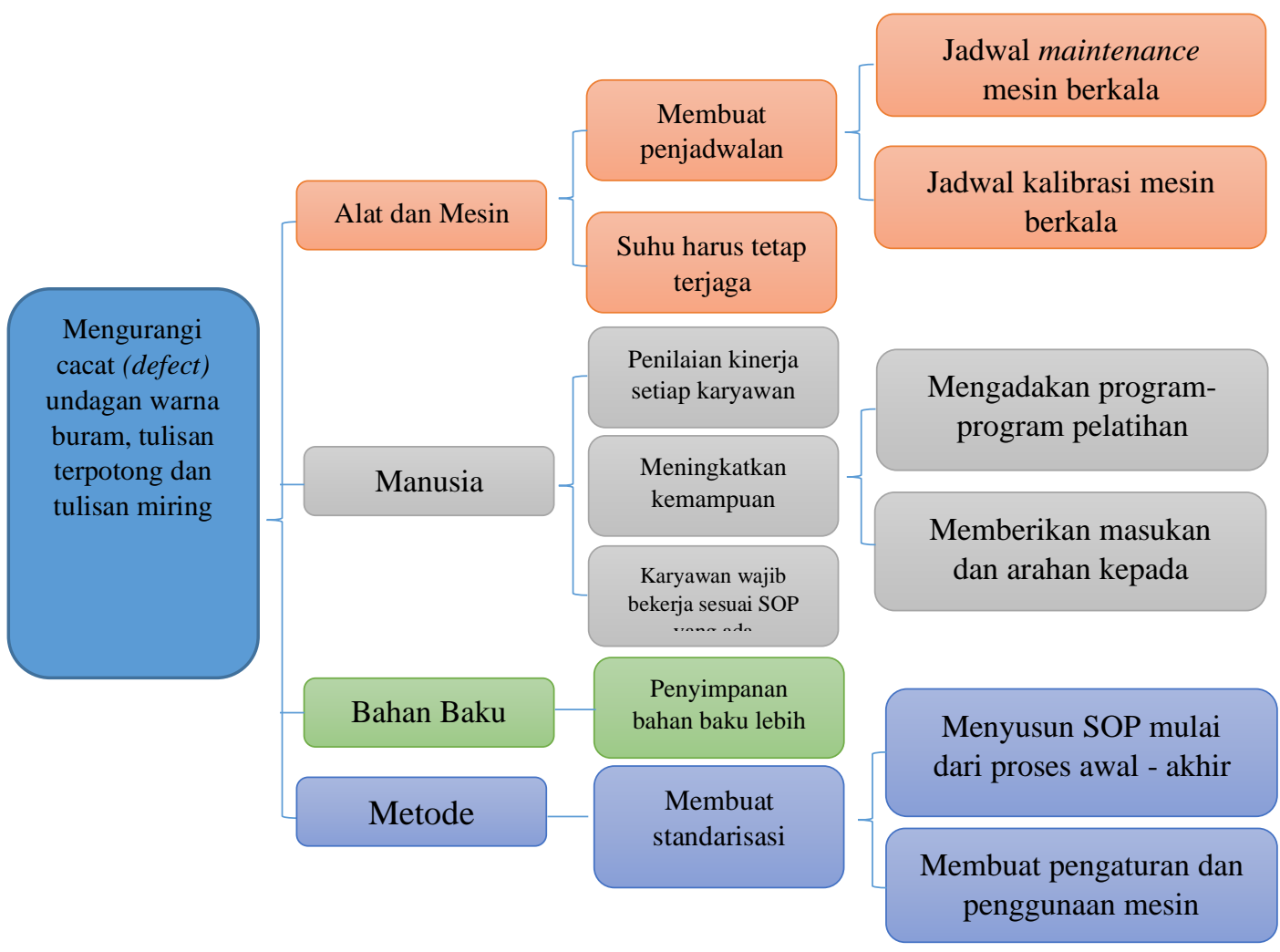

Sumber: Data yang telah diolah (2019)

Gambar 4 Diagram Solution Tree 
Tabel 2

Nilai DPMO dan Level Sigma bulan Januari - Maret Tahun 2019

\begin{tabular}{c|c|c|c|c|c}
\hline Bulan & $\begin{array}{c}\text { Jumlah } \\
\text { Produksi (buah) }\end{array}$ & $\begin{array}{c}\text { Produk } \\
\text { Cacat (buah) }\end{array}$ & $\begin{array}{c}\text { Present } \\
\text { ase }\end{array}$ & $\begin{array}{c}\text { Nilai } \\
\text { DPMO }\end{array}$ & $\begin{array}{c}\text { Level } \\
\text { Sigma (o) }\end{array}$ \\
\hline Januari & 9850 & 115 & $1.17 \%$ & 3891.71 & 4.2 \\
\hline Febuari & 11500 & 136 & $1.18 \%$ & 3942.03 & 4.2 \\
\hline Maret & 10200 & 120 & $1.18 \%$ & 3921.57 & 4.2 \\
\hline Total & $\mathbf{3 1 5 5 0}$ & $\mathbf{3 7 1}$ & $\mathbf{3 . 5 3 \%}$ & $\mathbf{3 9 1 9 . 7 0}$ & $\mathbf{4 . 2}$ \\
\hline
\end{tabular}

Sumber: Data yang telah diolah (2019)

Data pada tabel 2 menunjukkan bahwa semakin menurunnya jumlah kecacatan produk undangan yang dihasilkan dan meningkatnya level sigma. Sebelum perbaikan nilai DPMO pada bulan Januari-Maret 2018 adalah 8888,89 $(3,9 \sigma), 9109,73(3,9 \sigma)$, dan $11948,72(3,8 \sigma)$ dengan tingkat persentase cacat (defect) 2,67\%, 2,73\%, dan 3,58\%. Sesudah perbaikan untuk nilai DPMO dan level sigma, serta persentase produk cacat (defect) pada bulan Januari-Maret 2019 mengalami penurunan dari tahun lalu yaitu 3891,71 $(4,2 \sigma), 3942,03(4,2 \sigma)$, dan $3921,57(4,2 \sigma)$, dengan tingkat persentase cacat (defect) 1,17\%, 1,18\%, dan 1,18\%.

\section{Kesimpulan}

Perusahaan DA tidak menerapkan pengendalian kualitas apapun untuk hasil produknya dalam hal ini perusahaan masih fokus dengan apa yang dilihatnya langsung. Hasil perhitungan yang didapat bahwa hasil produksi percetakan undangan rata-rata berada pada tingkat sigma 3,9б. Pengendalian kualitas dengan menggunakan metode Six Sigma dapat menekan tingkat kecacatan (defect) pada perusahaan DA. 


\section{BIBLIOGRAFI}

Anwar, Ahmad Saiful, Narto, Narto, \& Achmadi, Fuad. (2017). Analisis Konsep Six Sigma Dan Continuous Improvement Untuk Mengeliminasi Defect Pada Produk Paper Packaging Di PT. XYZ. Prosiding SNST Fakultas Teknik, 1(1).

Gupta, Neha. (2013). An application of DMAIC methodology for increasing the yarn quality in textile industry. IOSR Journal of Mechanical and Civil Engineering (IOSR-JMCE), 6(1), 50-65.

Hasim, Lukman. (2019). Penerapan Business Intelligence Pada Manajemen Dashboard Report Perusahaan Asuransi. Syntax Literate; Jurnal Ilmiah Indonesia, 4(12), 123136.

Herdiana, D. S. (2015). Sardines product quality control in terms of HACCP to improve food security in Blambangan Foodpacker Indonesia company limited, Banyuwangi.

Kusumawati, Aulia, \& Fitriyeni, Lailatul. (2017). Pengendalian Kualitas Proses Pengemasan Gula Dengan Pendekatan Six Sigma. Jurnal Sistem Dan Manajemen Industri, 1(1), 43-48.

Manohar, C., \& Balakrishna, A. (2015). Defect Analysis on Cast Wheel by Six Sigma Methodology to reduce defects and Improve the Productivity in Wheel Production Plant. International Research Journal of Engineering and Technology (IRJET), 2(3), 1659-1663.

Oktavianus, Willy, \& Caesaron, Dino. (2017). Analisis Pengendalian Kualitas Cacat dengan Metode Six Sigma pada Perusahaan Percetakan (Studi Kasus: PT. Delta Mandiri). JIEMS (Journal of Industrial Engineering and Management Systems), $9(1)$.

Pande, Peter S., Neuman, Robert P., \& Cavanagh, Roland R. (2002). The Six Sigma Way-Bagaimana GE Motorola, dan Perusahaan Terkenal Lainnya Mengasah Kinerja Mereka. Andi Yogyakarta.

Pathak, Jayesh, \& Desai, Tushar N. (2011). Six Sigma quality management techniquean overview. Journal of Engineering Research and Studies, 2(3), 64-72.

Rimantho, Dino, \& Mariani, Desak Made. (2017). Penerapan metode six sigma pada pengendalian kualitas air baku pada produksi makanan. Jurnal Ilmiah Teknik Industri, 16(1), 1-12.

Sari, Diana Puspita. (2016). Aplikasi pendekatan six sigma dan kaizen untuk peningkatan kualitas pada proses produksi produk botol minum plastik tipe CB 061 di PT. Amp Demak.

Shofa, Mohamad Jihan, \& Gunawan, Hadi. (2017). Implementasi Six Sigma untuk Perbaikan Produk Nickel Pig Iron. Jurnal Sistem Dan Manajemen Industri, 1(1), 29-34. 